\title{
Characteristics of serological profile in adult measles patients depending on the development of complications
}

\author{
S. O. Bilokobyla ${ }^{\mathrm{B}, \mathrm{D}, \mathrm{C}}$, O. V. Riabokon ${ }^{(\mathrm{D}) \mathrm{A}, \mathrm{C,E}, \mathrm{F}}$, Yu. Yu. Riabokon ${ }^{\mathrm{C}, \mathrm{D}, \mathrm{E}}$, \\ N. V. Onishchenko $\mathbb{B}, C, D$
}

Zaporizhzhia State Medical University, Ukraine

A - research concept and design; B - collection and/or assembly of data; C - data analysis and interpretation; D - writing the article; $\mathrm{E}$ - critical revision of the article; $\mathrm{F}$ - final approval of the article

The aim - to determine the characteristics of serological profile in adult measles patients depending on the development of complications.

Material and methods. In total, 88 patients with measles aged between 21 and 53 years were followed-up ( 36 men and 52 women). Measles was diagnosed according to the WHO criteria (2013). All the patients were tested for measles virus IgM at the end of the first week of the disease to confirm the diagnosis. Measles IgG was measured using ELISA (Vircell Microbiologists, Spain) on hospital admission, on average the $(4.8 \pm 0.2)$ day of the disease, to determine probable post-vaccination immunity to measles.

Results. It was found that in most adult measles patients $(75.0 \%)$, the diagnosis was confirmed by the detection of IgM to measles virus at the end of the first week of the disease, while the other patients were diagnosed with measles by clinical and epidemiological criteria.

Most patients $(71.6 \%)$ were seropositive with the presence of measles virus $\lg G$ on the $4.8 \pm 0.2$ day of the disease, others had a negative $\mathrm{lg} \mathrm{G}$ serologic result. Complications of measles were diagnosed in the majority of adult patients $(76.1 \%)$, the frequency of which was associated $\left(X^{2}=4.84, \mathrm{P}<0.01\right)$ with seropositivity in this follow-up period, namely complications were more common in the seronegative patients $(92.0 \%)$ against $69.8 \%$ in the seropositive patients. Seronegative patients were more likely to have gastrointestinal complications as compared to seropositive individuals $\left(68.0 \%\right.$ vs. $30.2 \%, X^{2}=10.60$, $P<0.001)$ due to more frequent development of hepatitis $\left(68.0 \%\right.$ vs. $\left.28.6 \%, X^{2}=11.61, P<0.001\right)$. The frequency of two or more complications combined was also clearly correlated with the presence of measles virus lgG in patients on day $4.8 \pm 0.2$ of the disease $\left(X^{2}=7.70, P<0.01\right)$.

A comparison of the quantitative content of lgG against measles virus in seropositive adult measles patients showed an association with the development of complications: the highest level was detected in patients with uncomplicated measles amounting to 23.58 [21.87; 26.78] optical density units. In seropositive adult patients with measles-associated hepatitis, the measles virus IgG content was lower $(P=0.004)$ than that in patients with uncomplicated measles. A similar pattern was observed in pneumonia development $(P=0.0002)$. There were correlations between measles virus Ig $G$ content and platelet count $(r=+0.32, P<0.05)$, relative number of lymphocytes $(r=+0.46, P<0.05)$, ALT activity $(r=-0.45, P<0.05)$, relative number of band neutrophils $(r=-0.36, P<0.05)$.

Conclusions. In adult measles patients on day $4.8 \pm 0.2$ of the disease, seropositivity with measles virus IgG presence was observed in $71.6 \%$ of cases. Measles complications were recorded in $76.1 \%$ of adult patients. The incidence of complications was correlated with the presence of lgG against measles virus. Complications were more common in seronegative patients than in seropositive ones $(92.0 \%$ vs. $69.8 \%, P<0.01)$. The development of pneumonia $(P<0.01)$ and hepatitis $(P<0.01)$ was associated with the lowest level of measles virus $\lg G$.

\section{Особливості серологічного профікю в дорослих, які хворі на кір, залежно від розвитку ускиаднень}

\section{С. О. Білокобила, О. В. Рябоконь, Ю. Ю. Рябоконь, Н. В. Оніщенко}

Мета роботи -з'ясувати особливості серологічного профрілю дорослих, які хворі на кір, залежно від розвитку ускладнень.

Матеріали та методи. Під спостереженням перебували 88 хворих на кір віком від 21 до 53 років: 36 чоловіків, 52 жінки. Діагноз кору встановлювали за критеріями ВООЗ (2013). Усім хворим визначали IgM до вірусу кору наприкінці першого тижня захворювання для підтвердження діагнозу. Для з'ясування наявності ймовірно поствакцинальних антитіл під час надходження в стаціонар визначали IgG до вірусу кору на 4,8 \pm 0,2 дня хвороби (Vircell Microbiologists, Spain) методом IФА. Більшість хворих (71,6 \%) були серопозитивні з наявністю IgG до вірусу кору, серед них переважали пацієнти молодого віку (63,6 \%). Серед серонегативних пацієнтів найбільша частка $\left(X^{2}=4,04 ; p<0,01\right)$ хворих віком 25-44 років $-80,0 \%$ проти $57,1 \%$ серопозитивних.

Результати. Встановили, що в більшості дорослих, які хворі на кір (75,0\%), діагноз підтверджено виявленням IgM до вірусу кору наприкінці 1 тижня захворювання, в інших діагноз встановили за клініко-епідеміологічними критеріями. Більшість хворих (71,6 \%) на 4,8 \pm 0,2 дня хвороби були серопозитивні з наявністю $\lg G$ до вірусу кору, інші мали негативний результат. Ускладнення кору діагностовані в більшості дорослих хворих (76,1%), частота розвитку яких мала зв'язок $\left(x^{2}=4,84 ; p<0,01\right)$ із серопозитивністю в ці строки спостереження: ускладнення частіше зафріксовані в серонегативних хворих (92,0 \%), ніж у серопозитивних (69,8 \%). У серонегативних пацієнтів частіше, ніж у серопозитивних виявляли
Key words: measles in adults, serological tests, complications.

\section{Zaporozhye} medical journal 2020; 22 (6), 823-827

*E-mail: RyabokonZSMU@ukr.net 
ускладнення з боку шлунково-кишкового тракту (68,0 \% проти 30,2 \%, $\left.\chi^{2}=10,60 ; p<0,001\right)$ внаслідок частішого розвитку гепатиту $\left(68,0 \%\right.$ проти $\left.28,6 \%, X^{2}=11,61 ; p<0,001\right)$. Частота розвитку двох і більше ускладнень також чітко залежала від наявності IgG до вірусу кору в пацієнтів на 4,8 $\pm 0,2$ дня хвороби $\left(x^{2}=7,70 ; p<0,01\right)$.

Порівняння кількісного вмісту lgG до вірусу кору в серопозитивних дорослих хворих показало взаємозв'язок із розвитком ускладнень. Найвищий рівень зафіксували в пацієнтів із неускладненим перебігом кору, що становив 23,58 [21,87; $26,78]$ опт.од. У серопозитивних дорослих хворих на кір, що ускладний гепатитом, вміст $\lg \mathrm{g}$ до вірусу кору був нижчим ( $p=0,004)$, ніж у пацієнтів із неускладненим перебігом кору. Аналогічну закономірність визначили й у разі розвитку пневмонії ( $p=0,0002)$. Встановили кореляції вмісту IgG до вірусу кору з вмістом тромбоцитів $(r=+0,32, p<0,05)$, відносною кількістю лімфоцитів $(r=+0,46, p<0,05)$, активністю АлАТ $(r=-0,45, p<0,05)$, відносною кількістю паличкоядерних лейкоцитів $(r=-0,36, p<0,05)$.

Висновки. У дорослих дорослих, які хворі на кір, на 4,8 \pm 0,2 дня хвороби серопозитивність із наявністю $\lg$ до вірусу кору виявили в 71,6 \% випадків. Ускладнення кору зафіксували в 76,1 \% дорослих хворих. Частота розвитку ускладнень має взаємозв'язок із наявністю IgG до вірусу кору. Ускладнення частіше зафіксовані в серонегативних, ніж у серопозитивних пацієнтів $(92,0 \%$ проти 69,8 \%, $p<0,01)$. Розвиток пневмонії $(p<0,01)$ та гепатиту $(p<0,01)$ асоціюється з найнижчим рівнем $\lg \mathrm{g}$ до вірусу кору.

Ключевые слова: корь у взрослых серологический тест, осложнения.

Запорожский медицинский журнал. 2020. T. 22, № 6(123). C. 823-827

\section{Особенности серологического профиля у взрослых больных корью в зависимости от развития осложнений}

\section{С. А. Белокобыла, Е. В. Рябоконь, Ю. Ю. Рябоконь, Н. В. Онищенко}

Цель работы - выяснить особенности серологического профиля у взрослых больных корью в зависимости от развития осложнений.

Материалы и методы. Под наблюдением были 88 больных корью в возрасте от 21 до 53 лет: 36 мужчин, 52 женщины. Диагноз кори устанавливали по критериям ВО3 (2013). Всем больным определяли IgM к вирусу кори в конце первой недели заболевания для подтверждения диагноза. Для выяснения наличия вероятно поствакцинальных антител при поступлении в стационар определяли IgG к вирусу кори в среднем на 4,8 \pm 0,2 дня болезни (Vircell Microbiologists, Spain) методом ИФА. Большинство больных $(71,6 \%)$ серопозитивны с наличием IgG к вирусу кори, среди них преобладали пациенты молодого возраста (63,6 \%). Среди серонегативных пациентов больше всего $\left(X^{2}=4,04, p<0,01\right)$ больных в возрасте 25-44 лет - 80,0 \% против 57,1 \% серопозитивных.

Результаты. Установлено, что у большинства взрослых больных корью (75,0%) диагноз подтвержден обнаружением lgM к вирусу кори в конце 1 недели заболевания, у других диагноз кори установлен по клинико-эпидемиологическим критериям.

Большинство больных (71,6 \%) на 4,8 \pm 0,2 дня болезни серопозитивны с наличием IgG к вирусу кори, другие имели отрицательный результат. Осложнения кори диагностированы у большинства взрослых больных (76,1 \%), частота развития которых имела связь $\left(X^{2}=4,84, p<0,01\right)$ с серопозитивностью в эти сроки наблюдения: осложнения чаще зафиксированы у серонегативных больных (92,0 \%) по сравнению с серопозитивными (69,8 \%). У серонегативных пациентов чаще, чем у серопозитивных отмечены осложнения со стороны желудочно-кишечного тракта (68,0 \% против $\left.30,2 \%, X^{2}=10,60, p<0,001\right)$ за счет более частого развития гепатита $\left(68,0 \%\right.$ против $\left.28,6 \%, X^{2}=11.61, p<0,001\right)$. Частота развития двух и более осложнений также четко зависела от наличия IgG к вирусу кори у пациентов на 4,8 $\pm 0,2$ дня болезни $\left(X^{2}=7,70, p<0,01\right)$.

Сравнение количественного содержания IgG к вирусу кори у серопозитивных взрослых больных корью показало связь с развитием осложнений. Самый высокий их уровень зафиксирован у пациентов с неосложненным течением кори, составивший 23,58 [21,87; 26,78] опт.ед. У серопозитивных взрослых больных корью, которая осложнилась гепатитом, содержание $\operatorname{lgG}$ к вирусу кори было ниже ( $p=0,004)$, чем у пациентов с неосложненным течением кори. Аналогичная закономерность отмечена и при развитии пневмонии ( $p=0,0002)$. Установлены корреляции содержания IgG к вирусу кори с содержанием тромбоцитов ( $r=0,32, p<0,05)$, относительным количеством лимфоцитов $(r=+0,46, p<0,05)$, активностью АЛТ ( $r=-0,45, p<0,05)$, относительным количеством палочкоядерных лейкоцитов $(r=-0,36, p<0,05)$.

Выводы. У взрослых больных корью при поступлении на 4,8 \pm 0,2 дня заболевания серопозитивность с наличием IgG к вирусу кори отмечена в 71,6 \% случаях. Осложнения кори зафиксированы у 76,1% взрослых больных. Частота развития осложнений имеет связь с наличием IgG к вирусу кори на момент госпитализации. Осложнения чаще зафиксированы у серонегативных, чем у серопозитивных пациентов $(92,0 \%$ против 69,8%, p < 0,01). Развитие пневмонии ( $p<0,01)$ и гепатита ( $<$ < 0,01) ассоциируется с низким уровнем IgG к вирусу кори.

According to the WHO, in European countries, including Ukraine, there was a significant increase in measles patients in 2017-2019. In the first six months of 2019, almost 90 thousand cases of measles were detected, which was more than the number of reported cases for the whole of 2018 , when 84 thousand cases of this infection were registered. Ukraine headed the list of the top ten countries with the highest number of measles cases in 2018 [1].

Today, countries with high measles immunization coverage are still at risk of epidemic outbreak because of a change in the measles epidemiology over a long period of routine immunization owing to an increase in the adult population $[2,3]$. In these countries, there is a decrease in the content of post-vaccination lgG in adults, and possible consequences of this phenomenon during the elimination period remain unclear [4]. According to a number of researchers, adults under the age of 30 attract special attention, because the largest number of measles virus seronegative individuals (more than $40 \%$ ) is observed in an age group of 18-30 years [5]. Serological epidemiological stud- 
ies in Ukraine on the determining the most vulnerable age group of adults among population revealed persons aged 16 to 30 years, as only $78.1 \%$ of examined people had immunity against measles, which coincides with the high proportion of this age group among measles patients [6].

\section{Aim}

The purpose of the work is to determine the characteristics of serological profile in adult measles patients depending on the development of complications.

\section{Material and methods}

In total, 88 measles patients aged 21 to 53 years, the average age was $30.9 \pm 0.9$ years, were examined. They were hospitalized to the Municipal Institution "Regional Infectious Diseases Clinical Hospital”, Zaporizhzhia Regional Council, during 2017-2019. There were 36 men and 52 women. The diagnosis of measles was made according to the WHO criteria (2013). All measles patients included in the study reported measles childhood vaccination, but without documented evidence. All the patients were tested for measles virus $\operatorname{lgM}$ at the end of the first week of the disease to confirm the diagnosis. Measles IgG was measured using ELISA (Vircell Microbiologists, Spain) on hospital admission to determine probable post-vaccination immunity to measles. Special studies were performed on the basis of the Training and Laboratory Center of ZSMU headed by Professor Abramov A.V. Statistical data processing was performed in the program Sntatistica 13 for Windows (StatSoft Inc., No. JPZ804I382130ARCN10-J).

On day $4.8 \pm 0.2$ of the disease, most patients $(63.0-71.6 \%)$ were seropositive with the presence of measles virus $\lg$, and 25 (28.4\%) patients had a negative IgG serologic result. Among adult measles patients, young patients predominated ( $n=56 ; 63.6 \%$ ), only one of the three patients was middle-aged adult - 29 (33.0\%), late middle-aged adults were diagnosed with measles in isolated cases $(n=3 ; 3.4 \%)$. The analysis of measles virus $\lg G$ presence showed the largest proportion $\left(X^{2}=4.04\right.$, $P<0.01$ ) of patients aged 25 to 44 years among seronegative individuals amounting to $80.0 \%$ (20 of 25) against $57.1 \%$ (36 of 63 ) of seropositive ones (Fig. 1).

\section{Results}

According to the results of our study, in most adult measles patients ( $n=66 ; 75.0 \%$ ), the diagnosis was confirmed by the detection of $\operatorname{lgM}$ to measles virus at the end of the first week of the disease, while $22(25.0 \%)$ patients were diagnosed with measles by clinical and epidemiological criteria.

An analysis of measles virus lgG presence showed that most patients ( $n=63 ; 71.6 \%$ ) were seropositive on day $4.8 \pm 0.2$ of the disease, and $25(28.4 \%)$ patients had a negative result. At the same time, the majority of adult patients ( $n=67 ; 76.1 \%$ ) developed complications of measles. A comparison of complication incidence in adult patients with measles showed dependence $\left(X^{2}=4.84\right.$, $P<0.01)$ on a serologic status, namely seronegative patients developed complications significantly more often $23(92.0 \%)$ against $44(69.8 \%)$ seropositive patients. An

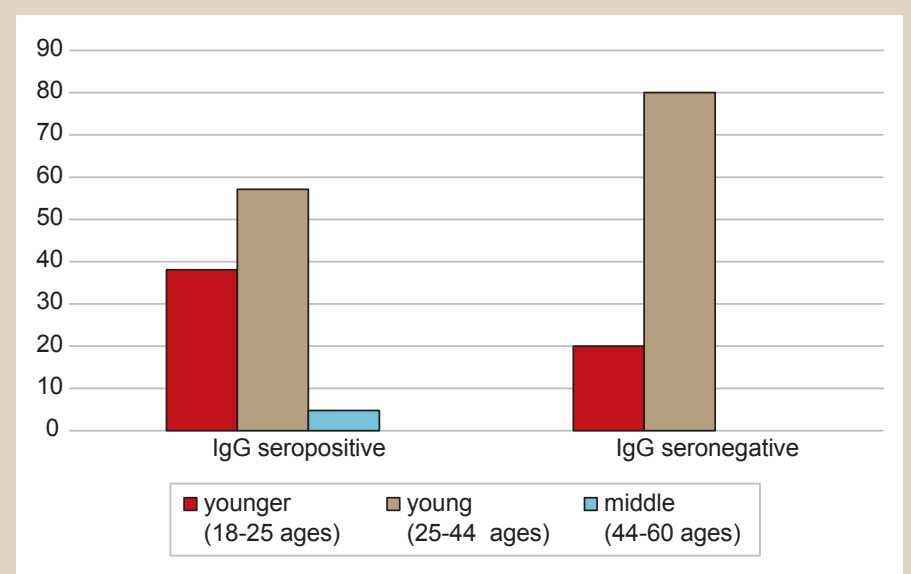

Fig. 1. Age structure among adult measles patients depending on the presence of measles virus IgG at hospital admission (*: the difference is significant compared with seropositive patients of the corresponding age group, $P<0.05)$.

Table 1. Comparison of complication incidence in adult measles patients depending on the presence of $\lg G$ to measles virus on day $(4.8 \pm 0.2)$ of the disease, abs $(\%)$

\begin{tabular}{|c|c|c|c|}
\hline \multirow[t]{2}{*}{ Indicator } & \multirow{2}{*}{$\begin{array}{l}\text { Patients } \\
\text { with measles } \\
\text { ( } n=88)\end{array}$} & \multicolumn{2}{|c|}{ Patients with measles } \\
\hline & & $\begin{array}{l}\text { IgG-positive } \\
(n=63)\end{array}$ & $\begin{array}{l}\text { IgG-negative } \\
(n=25)\end{array}$ \\
\hline Presence of complications & $67(76.1 \%)$ & $44(69.8 \%)$ & $23(92.0 \%)^{*}$ \\
\hline Respiratory complications, including: & $25(28.4 \%)$ & $19(30.2 \%)$ & $6(24.0 \%)$ \\
\hline Pneumonia & $5(5.7 \%)$ & $3(4.8 \%)$ & $2(8.0 \%)$ \\
\hline Acute bronchitis & $20(22.7 \%)$ & $16(25.4 \%)$ & $4(16.0 \%)$ \\
\hline Gastrointestinal complications, including: & $36(40.9 \%)$ & $19(30.2 \%)$ & $17(68.0 \%)^{*}$ \\
\hline Enteritis & $10(11.4 \%)$ & $6(9.5 \%)$ & $4(16.0 \%)$ \\
\hline Hepatitis & $35(39.8 \%)$ & $18(28.6 \%)$ & $17(68.0 \%)^{*}$ \\
\hline Combination of two or more complications & $36(40.9 \%)$ & $20(31.7 \%)$ & $16(64.0 \%)^{*}$ \\
\hline
\end{tabular}

*: difference is significant compared to lgG-positive patients $(P<0.05)$.

analysis of a range of measles-related complications in adults showed that seronegative patients, unlike patients with measles virus $\operatorname{lgG}$, were more likely to have gastrointestinal complications in the follow-up period $(68.0 \%$ vs. $\left.30.2 \%, X^{2}=10.60, P<0.001\right)$, primarily due to more frequent development of liver damage manifested as hepatitis (68.0\% vs. $\left.28.6 \%, X^{2}=11.61, P<0.001\right)$. Besides, a comparison of respiratory complications incidence did not reveal any statistically significant effect of measles virus IgG seropositivity at the time of hospital admission. However, the incidence of combination of two or more complications was clearly correlated with measles virus IgG presence in patients on day $4.8 \pm 0.2$ of the disease amounting to $64.0 \%$ (16 of 25$)$ in seronegative patients versus $31.7 \%$ (20 of 63 ) in seropositive patients $\left(X^{2}=7.70, P<0.01\right)$ (Table 1).

A quantitative content of measles virus lgG in seropositive adult measles patients was found to be correlated with the development of complications. Thus, a content analysis showed the highest level of measles-specific lgG in patients with uncomplicated measles amounting to 23.58 [21.87; 26.78] optical density units. In seropositive adult patients with measles complicated by hepatitis, the content of measles virus IgG was statistically significantly lower (18.67 [15.02; 24.05] optical density units $(P=0.004))$ 
Table 2. Measles-specific $\lg G$ content in seropositive adult measles patients depending on the development of complications, Me $\left[Q_{25} ; Q_{75}\right]$

\begin{tabular}{|c|c|c|c|}
\hline \multirow[t]{2}{*}{ Indicator } & \multicolumn{3}{|l|}{ Patients with measles } \\
\hline & $\begin{array}{l}\text { without complications } \\
(n=36)\end{array}$ & $\begin{array}{l}\text { pneumonia (including combination } \\
\text { with other complications) }(n=9)\end{array}$ & $\begin{array}{l}\text { hepatitis (including combination } \\
\text { with other complications) }(n=18)\end{array}$ \\
\hline Measles-specific lgG, optical density units & $23.58[21.87 ; 26.78]$ & $16.80[14.68 ; 20.26]^{*} P=0.0002$ & $18.67[15.02 ; 24.05]^{*} P=0.004$ \\
\hline
\end{tabular}

*: difference is significant compared to the corresponding indicators in patients without complications $(P<0.01)$.

than that in patients with uncomplicated measles. A similar pattern was observed in the development of pneumonia, namely the level of measles-specific $\lg G$ was 16.80 [14.68; 20.26] optical density units $(P=0.0002)$ in these patients (Table 2).

A correlation analysis confirmed the relationship between measles-specific lgG content and hematological parameters that reflected a severity of the disease and the development of complications. Thus, the quantitative content of measles virus $\lg$ directly correlated with the platelet count $(r=+0.32, P<0.05)$ and relative number of lymphocytes $(r=+0.46, P<0.05)$, and negatively correlated with serum ALT activity $(r=-0.45, P<0.05)$ and relative number of band neutrophils $(r=-0.36$, $P<0.05)$.

\section{Discussion}

Modern-day literature data on the incidence of measles complications in different age groups of patients are greatly variable, but show its clear dependence on the age of patients, in particular, children younger than 1 year and individuals older than 18 years are more likely to suffer from measles complications $[7,8]$. According to our study, the majority of adult measles patients, namely $76.1 \%$, had a complicated course of the disease.

The current epidemiological rise in measles incidence is gaining considerable attention among researchers due to a significant prevalence of previously vaccinated adults. In addition, it has been reported that immune response in such patients is characterized by rapid synthesis of measles-specific $\lg G$, while the $\lg M$ response to measles virus can be nominal or very short, which makes it difficult to serologically confirm the diagnosis and requires other methods of examination, particularly polymerase chain reaction to detect measles virus RNA [9]. However, the above dynamics of specific antibodies synthesis in these patients does not rule out the development of complications [10].

One of the most serious measles complications is pneumonia, and literature data on its development incidence in adult patients ranges from $15.3 \%$ [11] to $57.1 \%$ [12]. Such varying data can be explained by the use of different imaging methods to diagnose this complication, as confirmation of pneumonia in measles patients in some cases requires not only X-ray examination, but also computed tomography [13]. In our study, among hospitalized measles patients, a small number of patients $(5.7 \%)$ were diagnosed with pneumonia that can be explained by opportunity to confirm the development of this complication only according to chest X-ray examination. Moreover, our study has not revealed an association between pneumonia incidence and measles-specific $\operatorname{lgG}$ presence at the time of hospitalization among adult measles patients, but pneumonia has been found to correlate with the quantitative content of these antibodies.
The modern literature presents a large amount of study results demonstrating measles-associated pneumonia in individuals previously vaccinated for this infection $[10,14]$. Today, a number of studies attempt to address the issue of pathogenetic features of focal pneumonia development in individuals previously vaccinated for measles. In particular, it is assumed that the measles virus can replicate in local lymphoid tissue, then spread through the blood stream in individuals with waning post-vaccination immunity over time [15]. The occurrence of lung inflammatory foci is explained by type III hypersensitivity, as previously vaccinated patients respond to measles virus dissemination by a rapid production of measles-specific $\lg G$, which bind to the virus forming antigen-antibody complexes. As the measles virus is disseminated rapidly into many organs via viremia, similar foci of inflammation caused by immunocomplex mechanisms can be seen in other organs [16]. However, researchers believe that the mechanism of focal measles pneumonia in previously vaccinated individuals may differ from that in measles-associated lung infection in non-immune individuals [10]. It has been shown that foci of measles pneumonia in previously vaccinated individuals are common in the acute period of the disease, but the inflammatory foci show very long subsequent regression, usually within a few months [14]. Meanwhile, researchers have noted that in such patients, measles pneumonia is often focal and diagnosed better with computed tomography $[10,14]$. According to researchers [10], measles-associated pneumonia was evident in such patients only with an $\mathrm{lg} \mathrm{G} / \mathrm{lgM}$ ratio $>20$, which may be useful to diagnose measles pneumonia during outbreaks of this infection [10].

The latest studies indicate a high incidence of liver damage in adult measles patients $[17,18]$. The incidence of this complication in adult measles patients ranges from $45 \%$ [18] to $81 \%$ [17] against $1.4 \%$ in children [7]. According to our study, the incidence of hepatitis in adult measles patients was $39.8 \%$, and it was proved to be much higher in the absence of serum measles-specific $\mathrm{IgG}$ at the time of hospital admission than in seropositive individuals (68.0 \% vs. $28.6 \%, P<0.001)$. Resent data from the literature suggest that the risk of complications correlates with the severity of measles virus-induced immunosuppression in patients [19]. In conditions of secondary viremia, which is accompanied by clinical manifestations, the measles virus maximum amplification in the cells of lymphoid structures, respiratory system, gastrointestinal tract determines a number of complications. The process in these organs is serous-macrophage with lymphocytic infiltration and small-vessel vasculitis [20].

\section{Conclusions}

1. In adult measles patients on day $4.8 \pm 0.2$ of the disease, seropositivity with the presence of measles virus $\lg \mathrm{G}$ was observed in $71.6 \%$ of cases. 
2. Measles complications were recorded in $76.1 \%$ of adult patients. The incidence of complications was correlated with seropositivity and the presence of measles virus $\lg$ on day $4.8 \pm 0.2$ of the disease, namely complications were more common in seronegative patients than in seropositive ones (92.0 \% vs. $\left.69.8 \%, X^{2}=4.84, P<0.01\right)$.

3. The development of measles complications such as pneumonia $(P<0.01)$ and hepatitis $(P<0.01)$ was associated with the lowest level of measles virus $\lg G$.

Conflicts of interest: authors have no conflict of interest to declare. Конфлікт інтересів: віАсутній.

Надійшла до редакції / Received: 30.07.2020

Після Аоопрацювання / Revised: 14.09.2020

Прийнято Ао Аруку / Accepted: 24.09.2020

Information about authors:

Bilokobyla S. O., MD, Assistant of the Department of Infectious Diseases, Zaporizhzhia State Medical University, Ukraine. ORCID ID: 0000-0002-5673-616X

Riabokon O. V., MD, PhD, DSc, Professor, Head of the Department of Infectious Diseases, Zaporizhzhia State Medical University, Ukraine.

ORCID ID: 0000-0001-7781-991X

Riabokon Yu. Yu., MD, PhD, DSc, Professor of the Department of Children Infectious Diseases, Zaporizhzhia State Medical UniversityUkraine.

ORCID ID: 0000-0002-2273-8511

Onishchenko N. V., MD, Assistant of the Department of Infectious Diseases, Zaporizhzhia State Medical University, Ukraine. ORCID ID: 0000-0001-7775-7296

\section{Відомості про авторів:}

Білокобила С. О., асистент каф. інфекційних хвороб, Запорізький Аержавний медичний університет, Україна. Рябоконь О. В., А-р меА. наук, професор, зав. каф. інфекційних хвороб, Запорізький державний медичний університет, Україна. Рябоконь Ю. Ю., А-р меА. наук, професор каф. Аитячих інфекційних хвороб, Запорізький Аержавний меАичний університет, Україна.

Оніщенко Н. В., асистент каф. інфекційних хвороб, Запорізький Аержавний медичний університет, Україна.

\section{Сведения об авторах:}

Белокобыла С. А., ассистент каф. инфекционных болезней, Запорожский государственный медицинский университет, Украина.

Рябоконь Е. В., А-р меА. наук, профессор,

зав. каф. инфекционных болезней, Запорожский государственный медицинский университет, Украина. Рябоконь Ю. Ю., А-р меА. наук, профессор каф. Аетских инфекционных болезней, Запорожский государственный медицинский университет, Украина.

Онищенко Н. В., ассистент каф. инфекционных болезней, Запорожский госуАарственный меАицинский университет, Украина.

\section{References}

[1] Zadorozhna, V. I., Marychev, I. L., Protsap, O. I. \& Bryzhata, S. I. (2019). Epidemichna sytuatsiia po zakhvoriuvanosti na kir v Ukraini u 2017 - 2018 rr. [Epidemic situation on measles in Ukraine in 2017 2018]. Infectious diseases of the present: etiology, epidemiology, diagnosis, treatment, prevention, biological safety: Proceedings of the scientific-practical conference dedicated to the annual «Reading» in memory of L. V. Gromashevsky. (pp. 76-79), SPD FO «Kolomitsyn V. Yu.». [in Ukrainian].

[2] Hayman, D. (2019). Measles vaccination in an increasingly immunized and developed world. Human Vaccines \& Immunotherapeutics, 15(1), 28-33. https://doi.org/10.1080/21645515.2018.1517074
[3] Golubovska, O., Podolyuk, O., Ryabokon', E., \& Gainutdinova, T. (2018). Osobennosti klinicheskogo techeniya kori u vzroslykh v period epidemii 2018 goda [Features of the clinical course of measles in adults during the 2018 epidemic]. Klinicheskaya infektologiya $i$ parazitologiya, 7(4), 518-526. [in Russian].

[4] Gidding, H. F., Quinn, H. E., Hueston, L., Dwyer, D. E., \& McIntyre, P. B. (2018). Declining measles antibodies in the era of elimination: Australia's experience. Vaccine, 36(4), 507-513. https://doi.org/10.1016/j. vaccine.2017.12.002

[5] Toptygina, A. P., Smerdova, M. A., Naumova, M. A. Vladimirova, N. P. \& Mamaeva, T. A. (2018). Vliyanie osobennostei populyatsionnogo immuniteta na strukturu zabolevaemosti kor'yu i krasnukhoi [Influence of population immunity peculiarities on the structure of measles and rubella prevalence]. Infektsiya i immunitet, 8(3), 341-348. https://doi. org/10.15789/2220-7619-2018-3-341-348 [in Russian].

[6] Moyseyeva, A. V., Zadorozhna, V. I., Demchyshyna, I. V., \& Novyk, L. V. (2013). Monitorynh populiatsiinoho imunitetu proty koru naselennia Ukrainy [Monitoring of population's immunity is against measles of population in Ukraine]. Infektsiini khvoroby, (3), 10-15. https://doi. org/10.11603/1681-2727.2010.3.671 [in Ukrainian].

[7] Kramarov, S. O., Yevtushenko, V. V., Kovalyukh, I. Yu., Kaminska, T. M., \& Golovach, O. V. (2018). Klinichna kartyna koru v ditei, hospitalizovanykh pid chas spalakhu 2017-2018 rr. [Clinical features of measles in children hospitalized during 2017-2018 outbreak]. Aktual'naya infektologiya, 6(5), 240-245. https://doi.org/10.22141/2312413x.6.5.2018.146773 [in Ukrainian].

[8] Grammens, T., Schirvel, C., Leenen, S., Shodu, N., Hutse, V., Mendes da Costa, E., \& Sabbe, M. (2017). Ongoing measles outbreak in Wallonia, Belgium, December 2016 to March 2017: characteristics and challenges. Euro Surveillance, 22(17), Article 30524. https://doi. org/10.2807/1560-7917.ES.2017.22.17.30524

[9] Gibney, K. B., Attwood, L. O., Nicholson, S., Tran, T., Druce, J., Healy, J., Strachan, J., Franklin, L., Hall, R., \& Cross, G. B. (2020). Emergence of Attenuated Measles IIIness Among lgG-positive/lgM-negative Measles Cases: Victoria, Australia, 2008-2017. Clinical Infectious Diseases, 70(6), 1060-1067. https://doi.org/10.1093/cid/ciz363

[10] Yu, D., Zhang, G., Gao, L., Xu, W., \& Cao, B. (2018). High ratio of measles-specific $\mathrm{IgG} / \mathrm{lgM}$ associated with nodular pneumonia in vaccinated individuals. International Journal of Infectious Diseases, 76, 38-44. https://doi.org/10.1016/j.ijid.2018.08.015

[11] Monfort, L., Muñoz, D., Trenchs, V., Hernández, S., García, J. J., Aguilar, A. C., Juncosa, M. T., \& Luaces, C. (2010). Measles outbreak in Barcelona. Clinical and epidemiological characteristics. Enfermedades Infecciosas y Microbiologia Clinica, 28(2), 82-86. https://doi. org/10.1016/j.eimc.2009.05.006

[12] Premaratna, R., Luke, N., Perera, H., Gunathilake, M., Amarasena, P. \& Chandrasena, T. G. (2017). Sporadic cases of adult measles: a research article. BMC Research Notes, 10(1), Article 38. https://doi. org/10.1186/s13104-017-2374-6

[13] Trykhlib, V. I., Shchur, A. B., Hrushkevych, V. V., Hryshyn, O. S., Pavlovska, M. O., Musiienko, T. I., Muzyka A. A., Ralets, N. V., Dudar, D. M., \& Kozachenko, L. V. (2018). Osoblyvosti klinichnykh proiaviv ta perebihu koru [Peculiarities of measles clinical manifestations and course]. Aktual'naya infektologiya, 6(3), 141-152. https://doi.org/10.22141/2312413x.6.3.2018.136647 [in Ukrainian].

[14] Pang, M., Xu, J. Y., Li, P., Han, X. X., \& Li, M. Y. (2008). Clinical analysis of 51 cases of atypical measles syndrome characterized by fever and multiple lung lesions. Zhonghua Jie $\mathrm{He} \mathrm{He} \mathrm{Hu} X i \mathrm{Za} Z$ hi, 31(10), 731-735

[15] Moss, W. J. (2017). Measles. The Lancet, 390(10111), 2490-2502. https://doi.org/10.1016/S0140-6736(17)31463-0

[16] Melenotte, C., Cassir, N., Tessonnier, L., \& Brouqui, P. (2015). Atypical measles syndrome in adults: still around. BMJ Case Reports, 2015, Article bcr2015211054. https://doi.org/10.1136/bcr-2015-211054

[17] Dinh, A., Fleuret, V., \& Hanslik, T. (2013). Liver involvement in adults with measles. International Journal of Infectious Diseases, 17(12), e1243-e1244. https://doi.org/10.1016/j.ijid.2013.06.014

[18] Casanova-Cardiel, L. J., \& Hermida-Escobedo, C. (1994). Measles in the young adult. Clinical features of 201 cases. Revista de investigacion clinica; organo del Hospital de Enfermedades de la Nutricion, 46(2), 93-98.

[19] Laksono, B. M., de Vries, R. D., McQuaid, S., Duprex, W. P., \& de Swart, R. L. (2016). Measles Virus Host Invasion and Pathogenesis. Viruses, 8(8), Article 210. https://doi.org/10.3390/v8080210

[20] Shostakovych-Koretsraya, L. R., Mavrutenkov, V. V., Cherhinets, A. V., Budayeva, I. V., Yakunina, O. M., \& Chykarenko, Z. A. (2013). Kir (lektsiia, prodovzhennia) [Measles (lecture, continuing)]. Medychni perspektyvy, 18(4), C. 4-15. [in Ukrainian]. 